\title{
PENGENDALIAN Conopomorpha cramerella Snell MENGGUNAKAN FEROMON SEKS DI DESA MAKARTI JAYA KABUPATEN POHUWATO PROVINSI GORONTALO
}

\section{CONTROL OF Conopomorpha cramerella Snell USING PHEROMONE SEX IN MAKARTI JAYA VILLAGE POHUWATO DISTRICT GORONTALO PROVINCE}

\author{
Stevenlly J. Muliku'1), M. Tulung2), dan B.A.N. Pinaria2) \\ 1)Mahasiswa Entomologi Pascasarjana Unsrat Manado \\ 2)Fakultas Pertanian Unsrat Manado, 95115 \\ Email :stevenlymuliku@gmail.com
}

\begin{abstract}
Cocoa is one of the agricultural products that have a big role, especially in terms of employment, regional development, increasing farmer welfare and increasing revenues/foreign exchange. One of the main pests is the cruncher of cocoa $C$. cramerella Snell. The research aims to get the technology of environmentally friendly cacao borer pest control through the use of sex pheromone traps. The study was conducted in Makarti Jaya Village, Pohuwato District, Gorontalo Province for 3 months (January March 2017), using Randomized Block Design (RAK), with 3 treatments and 6 replications. The result of the research is the use of the six traps of pheromone sex succeeded in decreasing the intensity of PBK pest attack, after one month of attack intensity attack trapping decreased to $2.23 \%$, lower than pesticide application which only $4.49 \%$.
\end{abstract}

Keywords: pheromone sex Conopomorpha cramerella Snell, cacao fruit snipper

\begin{abstract}
ABSTRAK
Kakao merupakan salah satu produk pertanian yang memiliki peran yang besar, khususnya dalam hal penyediaan lapangan kerja, pendorong pengembangan wilayah, peningkatan kesejahteraan petani dan peningkatan pendapatan/devisa negara. Salah satu hama utama adalah penggerek buah kakao $C$ cramerella Snell. Penelitian bertujuan untuk mendapatkan teknologi pengendalian hama penggerek buah kakao yang ramah lingkungan melalui penggunaan perangkap feromon seks. Penelitian ini dilaksanakan di Desa Makarti Jaya, Kabupaten Pohuwato, Provinsi Gorontalo selama 3 bulan (JanuariMaret 2017), menggunakan Rancangan Acak Kelompok (RAK), dengan 3 perlakuandan 6 ulangan. Hasil penelitian yang didapat adalah penggunaan 6 perangkap feromon seks berhasil menurunkan intensitas serangan hama PBK, setelah satu bulan pemasangan perangkap intensitas serangan menurun hingga 2,23\%, lebih rendah dari aplikasi pestisida yang hanya $4,49 \%$.
\end{abstract}

Kata kunci : feromon seks Conopomorpha cramerella Snell, penggerek buah kakao 


\section{PENDAHULUAN}

Kakao merupakan salah satu produk pertanian yang memiliki peranan yang besar, khususnya dalam hal penyediaan lapangan kerja, pendorong pengembangan wilayah, peningkatan kesejahteraan petani dan peningkatan pendapatan/ devisa negara. Hal ini dikarenakan sebagian besar perkebunan kakao di Indonesia merupakan perkebunan rakyak.

Indonesia merupakan salah satu pembudidaya tanaman kakao terbesar di dunia dengan areal per tanaman seluas 1.462 .000 ha dan produksi per tahun mencapai 1.315 .800 ton. Sentra kakao di Indonesia tersebar di Sulawesi $(63,8 \%)$, Sumatera $(16,3 \%)$, Jawa $(3,6 \%)$, Maluku dan Papua $(7,1 \%)$ (Anonim, 2010).

Salah satu faktor pembatas budidaya kakao adalah adanya serangan hama penggerek buah kakao (PBK) Conopomorpha cramerela Snellen (Lepidoptera: Gracillaridae). Hama PBK dapat menurunkan produksi sampai $80 \%$ dan kerusakan biji sampai $82 \%$ (Pristiarini, 2012).

Penggerek buah kakao (PBK) menyerang buah-buah kakao mulai dari yang masih muda dengan panjang sekitar $8 \mathrm{~cm}$ sampai buah menjelang masak. Serangan yang terjadi pada saat buah muda akan mengakibatkan kerusakan lebih berat dibandingkan serangan saat buah menjelang masak. Stadium yang menimbulkan kerusakan adalah stadium larva. Larva PBK memakan daging buah dan saluran makanan yang menuju biji, tetapi tidak menyerang biji. Gejala serangan baru tampak dari luar pada saat buah mulai dewasa yaitu kulit buah warnanya pudar dan timbul belang berwarna hijau kuning atau merah jingga, dan apabila buah dikocok tidak berbunyi. Jika dibelah, daging buahnya akan tampak berwarna hitam, biji-biji melekat satu sama lain, warnanya hitam, keriput dan ringan (Anonim, 2015).

Standar operasional pengendalian (SOP) PBK di daerah yang masih bebas dari serangan PBK adalah melakukan karantina dan monitoring. Sedangkan SOP di daerah serangan PBK dibagi menjadi teknik pengendalian yang wajib dilakukan jika serangan PBK masih tinggi dan dirasakan merugikan. SOP yang wajib dilakukan adalah pe- mangkasan, pemupukan, panen sering dan sanitasi yang dikenal dengan P3S atau sebelumnya dikenal pengendalian hayati, penyarungan buah, penyemprotan insektisida, pemasangan perangkap feromon dan pemanfaatan tanaman tahan (Anonim 2015).

Tujuan penelitian untuk mendapatkan teknologi pengendalian hama penggerek buah kakao yang ramah lingkungan melalui penggunaan perangkap feromon seks

\section{METODE PENELETIAN}

Penelitian dilaksanakan di Desa Makarti Jaya, Kecamatan Taluditi, Kabupaten Pohuwato, Provinsi Gorontalo pada bulan Januari-April 2017.

Penelitian menggunakan Rancangan Acak Kelompok (RAK) dengan membagi dalam 3 unit pengamatan (masing-masing 1 ha), masing-masing unit pengamatan dibagi menjadi 6 petak yang masing-masing petak diambil 10 pohon kakao yang dilakukan dengan sengaja.

Pada ketiga unit percobaan terdiri dari 3 perlakuan $\times 6$ ulangan $\times 10$ pohon $=180$ pohon yang terdiri dari :

1. Kontrol

2. Perlakuan Pestisida

3. Penggunaan Perangkap Feromon Seks

Perlakuan masing-masing dilakukan dengan enam kali ulangan tiap 10 pohon kakao. Penelitian dilakukan pada hamparan kebun kakao seluas \pm 3 ha. Pengamatan dilakukan setiap 10 hari setelah pemasangan perangkap.

Prosedur penelitian yang digunakan meliputi persiapan lahan yaitu dengan mempersiapkan lahan perkebunan kakao yang akan dilakukan pengendalian hama PBK. Unit pengamatan kontrol dibiarkan tanpa ada aplikasi pestisida maupun perangkap feromon seks. Unit pengamatan dengan aplikasi pestisida, setiap 10 hari. Unit pengamatan feromon seks dilakukan dengan pemasangan perangkap feromon seks pada lokasi penelitian sebanyak 6 buah. Melakukan pengamatan hama PBK yang tertangkap pada perangkap setiap 10 hari.

Buah kakao yang berukuran $10-12 \mathrm{~cm}$ diambil setiap 30 hari dari setiap unit pengamatan dan diamati intensitas serangan hama PBK. 
Parameter pengamatan meliputi intensitas serangan dan kehilangan hasil akibat serangan PBK. Untuk menghitung intensitas serangan akibat serangan PBK dapat dihitung dengan menggunakan rumus (Anonim, 2013) :

$$
I=\frac{(0 . S h+1 \cdot R+3 \cdot S+9 . B)}{\text { jumlah buah diamati }}
$$

$\mathrm{I}=$ Intensitas Serangan

Sh = Jumlah Buah Sehat

$\mathrm{R}=$ Jumlah Buah Rusak Ringan

$S$ = Jumlah Buah Rusak Sedang

$\mathrm{B}=$ Jumlah Buah Rusak Berat

Kehilangan hasil akibat serangan PBK dapat dihitung dengan menggunakan persamaan regresi sebagai berikut :

$$
Y=-0,0210+0,1005 X
$$

$Y=$ Kehilangan hasil

$X=$ Intensitas serangan

\section{HASIL DAN PEMBAHASAN}

Pengendalian PBK melalui penangkapan (trapping) imago PBK menggunakan feromon seks saat ini sudah mulai dikembangkan. Feromon ini merupakan senyawa sintetik dari ekstrak senyawa feromon seks yang dikeluarkan imago betina PBK.

Intensitas serangan PBK pada perlakuan dengan menggunakan perangkap feromon seks mengakibatkan penurunan intensitas serangan yang lebih baik dibandingkan dengan perlakuan menggunakan pestisida dimana pada pengamatan pertama (30 hari) setelah pemasangan perangkap intensitas serangan sebesar 2,23\% lebih rendah dibandingkan dengan perlakuan menggunakan pestisida yang intensitas serangannya sebesar $4,49 \%$. Pengamatan kedua (60 hari) setelah pemasangan perangkap intensitas serangan sebesar $0,84 \%$ lebih rendah dibandingkan dengan perlakuan menggunakan pestisida sebesar 3,94\% dan pengamatan ketiga (90 hari) setelah pemasangan perangkap intensitas serangan $0,00 \%$ lebih baik dibandingkan perlakuan menggunakan pestisida dengan intensitas serangan $1,43 \%$. Intensitas serangan tersebut dapat dilihat pada Gambar 1.

PBK yang terperangkap pada perangkap feromon seks juga memperlihatkan kecenderungan penurunan jumlah serangga PBK yang tertangkap. Data serangga PBK yang tertangkap dapat dilihat pada Tabel 1.

Jumlah PBK yang terperangkap tertinggi pada pengamatan pertama (sepuluh hari setelah pemasangan perangkap), sebesar 103 ekor PBK dengan rata-rata jumlah PBK terperangkap 17,17 ekor per perangkap dan jumlah PBK yang terperangkap terendah pada pengamatan ke 9 (sembilan puluh hari setelah pemasangan perangkap) dengan jumlah PBK terperangkap 15 ekor dengan rata-rata jumlah PBK terperangkap 2,50 ekor per perangkap. Hasil ini menunjukkan bahwa pemasangan perangkap feromon seks dapat mengendalikan populasi hama PBK.

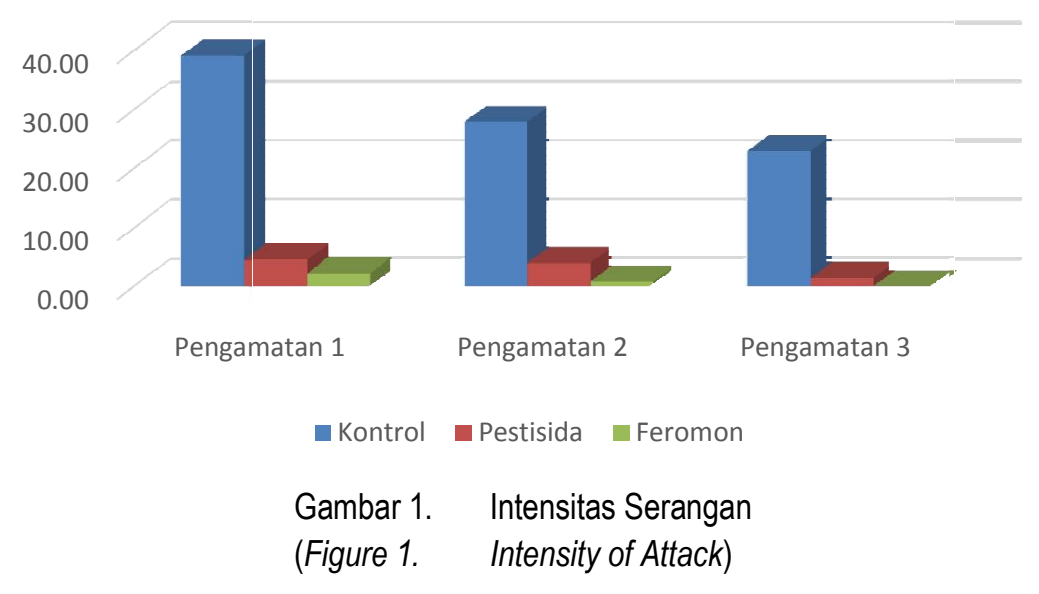


Tabel 1. Jumlah PBK Yang Terperangkap Pada Perangkap Feromon Seks

(Table 1. Number of PBK Trapped in Sex Pheromone Traps)

\begin{tabular}{ccc}
\hline Pengamatan & Jumlah PBK Terperangkap (ekor) & $\begin{array}{c}\text { Rata-rata PBK Terperangkap } \\
\text { (ekor) }\end{array}$ \\
\hline 1 & 103 & 17,17 \\
2 & 63 & 10,50 \\
3 & 52 & 8,67 \\
4 & 37 & 6,17 \\
5 & 29 & 4,83 \\
6 & 26 & 4,33 \\
7 & 24 & 4,00 \\
8 & 21 & 3,50 \\
9 & 15 & 2,50 \\
\hline
\end{tabular}

Hasil penelitian Sulistyowati dan E. Sulistyowati (1993) serangan PBK pada tingkat serangan ringan sudah mengakibatkan kerugian yang cukup besar yaitu menurunkan berat biji basah, rendemen dan mutu.

\section{KESIMPULAN DAN SARAN}

Penggunaan 6 perangkap feromon seks/ ha pada pertanaman kakao lebih efektif dan ramah lingkungan dalam mengendalikan hama PBK dibandingkan dengan aplikasi pestisida.

\section{DAFTAR PUSTAKA}

Anonim. 2010. Buku Pintar Budi Daya Kakao. Pusat Penelitian Kopi dan Kakao Indonesia, AgroMedia Pustaka, Jakarta.
Anonim. 2013. Panduan Lengkap Kakao Manajemen Agribisnis dari Hulu Hingga Hilir. Pusat Penelitian Kopi dan Kakao Indonesia, Penebar Swadaya, Jakarta

Anonim. 2015. Kakao Sejarah, Botani, Proses Produksi, Pengolahan, dan Perdagangan. Pusat Penelitian Kopi dan Kakao Indonesia, Gadjah Mada University Press.

Pristiarini, W. 2012. Pengenalan Hama Penting Kopi dan Kakao. http://wantypristiarini. blogspot.com/2012/01/laporan-7.html. DiaksesTanggal11 Agustus 2016.

Sulistyowati dan E. Sulistyowati. 1993. Pengaruh Serangan Hama Penggerek Buah Kakao (PBK) terhadap Mutu Biji Kakao. Warta Pusat Penelitian Kopi danKakao. 